\title{
The Development of Sensitive and Selective Potentiometric Biosensor for Urea Assay
}

\author{
Manihar Situmorang ${ }^{1}$, Primsa Kaban ${ }^{2}$, Rhica Ayulinova ${ }^{3}$, and Wesly Hutabarat ${ }^{4}$ \\ $\left\{\right.$ msitumorang@unimed.ac.id $\left.{ }^{1}\right\}$ \\ Department of Chemistry, Faculty of Mathematics and Natural Science, Universitas Negeri \\ Medan ${ }^{1,2,3,4}$
}

\begin{abstract}
The development of the biosensor as a step to obtain analytical instrument for urea is explained in this study. The aim of this research is to obtain sensitive and selective potentiometric biosensor for urea assay in clinical sample. The study was conducted through preparation of an enzyme electrode with immobilisation of urease onto the tungsten wire by using matrix polymer, followed by interfacing the sensing device vs $\mathrm{Ag} / \mathrm{AgCl}$ with voltmeter that was connected with Powerlab for data aquisition. The presence of urease in the sensing device is catalytically converted the urea to ammonium ion and bicarbonate which results in the potential change in electrochemical cell. The wide linearity range for urea standard solution was obtained $(0.1-10 \mathrm{mM}$ urea) with slope $42.7 \mathrm{mV}$ per-decade urea concentration $(\mathrm{r} 2=0.993)$. The urea biosensor gives sensitive response to urea where the detection a limit was $0.1 \mathrm{mM}$ urea. A very fast analytical response was achieved that was only taken four minute per-sample. The potentiometric urea biosensor developed in this study is promising since the instrumentation component is relatively inexpensive and can be modified to an portable mini biosensor.
\end{abstract}

Keywords: Potentiometric biosensor, tungsten wire electrode, sensitive and selective response, urea assay.

\section{Introduction}

The challenges to provide sensitive and selective biosensors is continue in analytical methodology and as they become important parameter in the successful of the biosensor construction. The quantitative analysis results obtained from the biosensors must be directly related to true value of the analyte in the sample (Situmorang and Nurwahyuni, 2018; Situmorang and Nurwahyuni, 2017). One approach to provide accurate analytical determination for urea was using potentiometric biosensor with incorporation of enzyme urease as catalytic agent in the electrode. The enzyme was immobilised on to the electrode surface by using various type of matrix polymers that were compatible with electrochemical detection systems (Situmorang, et al., 1998). The preparation of urea biosensor is needed as a step to provide a sensitive and selective analytical instrument for urea. It is known that the presence of urea at a certain level in blood and other body fluids can be used as indicators for some diseases (Friedman and Juneja, 2014; Alqasaimeh, et al., 2014). With this reason, a sensitive and selective method is needed to assure accurate urea measurement has been proceeded. A standard procedures with UV-Vis spectrophotometry is still been applied for urea where this analytical protocol is subject to interference from interfering species 
(Situmorang, et al., 2010). Another methods for urea determination have been introduces such as reflectometry (Ulianas, et al., 2011; Alqasaimeh, et al., 2007), colorimetry (Gaddes, et al., 2015; Zawada, et al., 2009; Sharma, et al., 2009), nuclear magnetic resonance (Liu, et al., 2012), LC-MS (Pitiranggon, et al., 2014), field effect transistor (Chang, et al., 2010; Lue, et al., 2011), acoustic wave (Tan, et al., 1998), and electrochemical methods (Ma, et al., 2016; Manea, et al., 2008; Ho, et al., 1999; Hilding-Ohlsson, et al., 2012; Das and Yoon, 2015). Most of the previous methods are operated with relatively expensive instrumentation.

The development potentiometric biosensor becomes an alternative to obtain a sensitive and selective analytical device with low cost instrumentation. The method have been introduced in the previous study (Sihombing, et al., 2018; Sihombing, et al., 2017). It is by the immobilisation of urease in a polymer matrix polymer (Sihombing, et al., 2015). A tungsten wire electrodes was used as transducers similar to malate biosensors (Situmorang, et al., 2001). The compatibility of tungsten electrode in potentiometric measurement is exploited in the construction of urea biosensor. The study is aimed to present the development of a sensitive and selective potentiometric biosensor for the determination of urea. The detection system is based on the catalytic conversion of urea to ammonium ion and bicarbonate that can be monitored potentiometrically by the biosensor device.

\section{EXPERIMENTAL}

\subsection{Reagents and Apparatus}

Analytical grade of urea, Urease (EC 3.5.1.5) from Canavaliaensiformis (jack bean) Type IX (75,265 units/gram solid), tris[hydroxymethyl] aminomethane hydrochloride (trismaHCl), and were obtained from Sigma Chem. Co. Another chemical such as Polyvinyl Alcohol (PVA), Poly(vinyl chloride) (PVC: low molecular weight type), 2-nitrophenyl octyl ether (NPOE) as membrane plasticizer, potassium tetrakis (p-chlorophenyl) borate (KTpCIPB) as anionic additive, 2-chloromethylquinoline, solvent of tetrahydrofuran (THF), K2HPO4, KH2PO4, $\mathrm{KCl}$, and $\mathrm{HCl}$ were purchased from Aldrich Chem. Co. The reagents were used without purification and Milli-Q water was used for all solutions.

A Keithley 177-Microvolt Digital Multi Meter (Keithley Instrument, USA) connecting with Powerlab 2/20 AD Instrument was used for data acquisition. Working electrode of tungsten wire, $1 \mathrm{~mm}$ diameter (Aldrich Chem. Co.) in combination with $\mathrm{Ag} / \mathrm{AgCl}$ reference electrode were used in all potentiometric measurements.

\subsection{Preparation of Potentiometric Biosensor}

The development of potentiometric urea biosensor was carried out similar to that explained in previous study with modification for a better response in the sensitivity and selectivity of sensing device (Sihombing, et al., 2018; Sihombing, et al., 2017). Briefly, the urease was immobilised onto tungsten (W) electrodes by the use of PVA matrix followed by sealing with plasticized PVC to produce enzyme working electrode (W/Ur-PVA/PVC). The enzyme electrode was then combined with $\mathrm{Ag} / \mathrm{AgCl}$ reference electrode in an electrochemical cell. The electrodes are then connected to potentiometer with Powerlab 2/20 for data acquisition. 


\subsection{Potentiometric Measurements}

Determination of urea by using urea biosensor was conducted in $0.01 \mathrm{M}$ trisma buffer solution, pH 6.0. Successive injections of urea standard solutions (from a stock solution of 1 M urea) were made after a steady potential background was obtained with continuous record of the potential change produced by the enzymatic catalytic reaction of urea at optimum experimental conditions (Situmorang, et al., 1998). The potential was recorder as a function of urea concentration. The biosensor is then evaluated based on its performance for urea assay in the response sensitivity, working range, selectivity and biosensor stability.

\section{RESULTS AND DISCUSSION}

\subsection{Biosensor Response to Urea Standard Solution}

The response of urea biosensor to urea standard solution has been obtained as presented in Figure 1. With the biosensor (W/Ur-PVA/PVC), the potential increased with increasing the concentration of urea in the solution (Figure 1a). As a comparison, there is no potential change observed when injection of the same amount of urea standard solution into the solution when the determination was made by modified electrode (W/PVA/PVC). in the absence of urease (Figure 1b).

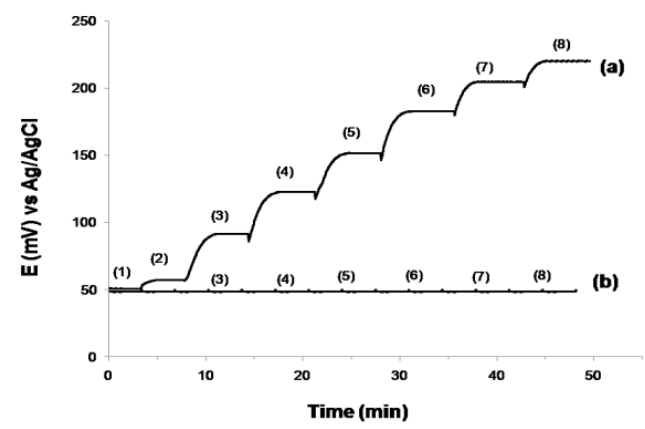

Figure 1. Typical potential-time curve for successive injection of urea standard solution: (1) $0.0 \mathrm{mM}$, (2) $0.01 \mathrm{mM}$, (3) $0.1 \mathrm{mM}$, (4) $0.5 \mathrm{mM}$, (5) $1.0 \mathrm{mM}$, (6) $5.0 \mathrm{mM}$, (7) $10.0 \mathrm{mM}$ and (8) $50 \mathrm{mM}$ urea into $0.01 \mathrm{M}$ trisma buffer solution, $\mathrm{pH} 6.0$ that were detected by using: (a) enzyme electrode (W/Ur-PVA/PVC), and (b) modified electrode in the absence of urease (W/PVA/PVC). The enzyme electrode was constructed by coating the tungsten wire electrode with PVA containing urease one time.

The results reveal that a sensitive signal was obtained by the urea biosensor, and the signal for urea was about five minute per sample starting from injection until the steady baseline when completing the enzymatic reaction of urea. The biosensor gave linear response to urea in the concentration range of $0.01-10 \mathrm{mM}$ urea (Figure 2), with a calibration slope of $42.7 \mathrm{mV}$ decade- 1 urea concentration, and the detection limit $0.01 \mathrm{mM}$ urea (Sihombing, et al., 2018). 


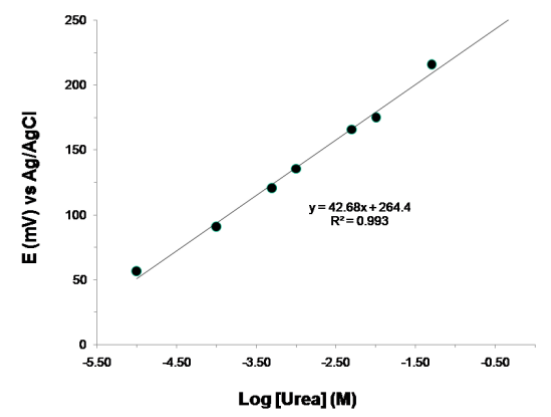

Figure 2.The calibration curve for urea standard solution $(0.01-10 \mathrm{mM}$. The experimental conditions are shown in Figure 1.

\subsection{Selectivity of Urea Biosensors}

To evaluate the selectivity of the biosensor upon interfering species, various types of analytes that possibly presents in clinical samples were added into urea standard solution, and the potential of each sample was measured separately (Situmorang, et al., 2000). The potential response for $1 \mathrm{mM}$ of urea mixed with $1 \mathrm{mM}$ interfering analytes are also measured in comparison to a single interfering species. The potential result obtained by the biosensor was summarized in Table 1. It showed that small potential was obtained for interfering species alone, that is closed to the potential value of background trisma buffer solution. However, when the analyte $(1 \mathrm{mM}$ interfering agent) was mixed with $1 \mathrm{mM}$ urea, the presence of interfering species in urea standard solution did not influence the response sensitivity of urea measurement. This results confirmed that the use of PVA as matrix polymer and the sealing process provided by plasticised PVC improve the selectivity of the biosensor (Situmorang, 2012).

Table 1. Potential response of urea biosensor to $1 \mathrm{mM}$ urea standard solution and interfering species, and the mixture of urea and interfering species $(1 \mathrm{mM})$. Experimental parameters are shown in figure 1.

\begin{tabular}{|c|c|c|c|c|}
\hline \multirow[b]{2}{*}{ No } & \multirow{2}{*}{$\begin{array}{c}\text { Urea and analytes as } \\
\text { interfering species (1 } \\
\mathrm{mM})\end{array}$} & \multicolumn{3}{|c|}{ Potential response of urea biosensor E (mV) } \\
\hline & & $\begin{array}{l}\text { Interfering species alone (1 } \\
\mathrm{mM}), \mathrm{E}(\mathrm{mV})\end{array}$ & $\begin{array}{l}\text { Mixture of } 1 \mathrm{mM} \text { urea and } 1 \mathrm{mM} \\
\text { interfering species, } \mathrm{E}(\mathrm{mV})\end{array}$ & $\Delta \mathrm{E}(\mathrm{mV})^{*}$ \\
\hline 1 & Urea & 135.5 & 135.5 & 0.0 \\
\hline 2 & Glucose & 47.5 & 137.1 & 1.6 \\
\hline 2 & Fructose & 49.5 & 138.4 & 2.9 \\
\hline 3 & Cholesterol & 51.5 & 137.2 & 1.7 \\
\hline 5 & Ascorbic acid & 92.0 & 125.5 & -10.0 \\
\hline 6 & Potassium ion & 47.5 & 135.0 & -0.5 \\
\hline 7 & Calcium ion & 49.2 & 134.1 & -1.4 \\
\hline
\end{tabular}


*The potential electrode $\mathrm{E}(\mathrm{mV})$ form the mixture of urea and interfenren - $\mathrm{E}(\mathrm{mV})$ urea standard solution, where the potential background from trisma buffer solution $(0.01 \mathrm{M}, \mathrm{pH} 6.0)$ was $47.7 \mathrm{mV}$.

\subsection{Stability of Urea Biosensor}

The stability of enzyme electrode has been evaluated. Four electrodes were prepared, and the response stability was evaluated with variation in the storage of the electrode in the solution and in dry condition (Situmorang, et al., 2002). The response signal for enzyme electrode at different storage condition is presented in Figure 3. The biosensor gave a stable response when it is store dry both in the fridge (Figure 4a) and room temperature (Figure 4b), where the potential change reduce down to about $10 \%$ after 35 days compare to fresh electrode. The potential signal obtained from enzyme electrodes were significantly decreased when they are stored in buffer solutions (Figure 3c and Figure 3d). The results confirmed that dry condition is the best environment to store the enzyme electrodes, This stored condition for immobilised enzyme by using PVA was similar with enzyme immobilisation in polytyramine matrix polymer (Situmorang, et al., 1999).

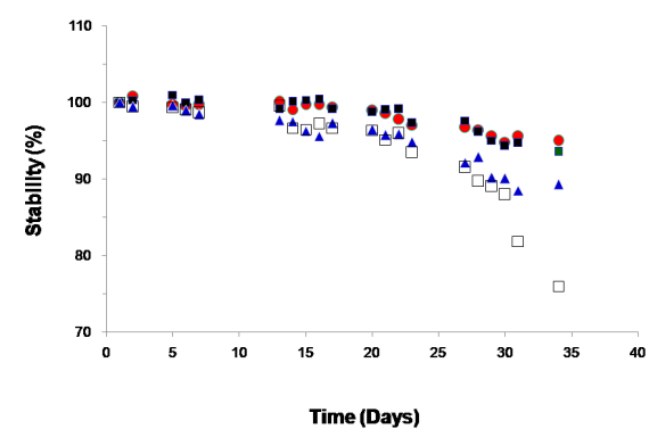

Figure 3.The stability of urea biosensors for repeated measurements of $1 \mathrm{mM}$ urea standard solution, where the biosensor was stored differently: $(\bullet)$ Biosensor 1 stored dry in at $4{ }^{\circ} \mathrm{C},(\boldsymbol{\bullet})$ Biosensor 2 stored dry at room temperature, $(\boldsymbol{\Delta})$ Biosensor 3 stored in trisma buffer $\mathrm{pH} 6,0$ at $4{ }^{\circ} \mathrm{C},(\square)$ Biosensor 4 stored in trisma buffer at room temperature. Other experimental parameters are as in figure 1.

\section{CONCLUSION}

Urea biosensor has been developed with immobilisation of urease in PVA matrix. The biosensor gave a sensitive and selective response to urea, only five minutes per sample from injection until obtaining a steady potential baseline. The concentration linearity range was obtained from 0.01 - $50 \mathrm{mM}$ urea, slope of $42.7 \mathrm{mV}$ decade- 1 urea, and the detection limit was $0.01 \mathrm{mM}$ urea. The potentiometric biosensors is stable for longer uses when stored in dry condition. The biosensor is very promising since it is prepared from relatively low cost instrumentation components. 
Acknowledgments. Funding support for this work was obtained from Directorate Research and Community Service, Directorate General Strengthen Research and Development, Ministry of Research, Technology and Higher Education of the Republic of Indonesia, Under Penelitian Strategis Nasional Institusi, contract No. 073/SP2H/LT/DRPM/2018

\section{References}

[1] Alqasaimeh, M, Heng, L.Y., Ahmad, M., Raj, A.S.S., and Ling, T.L.,2014. A Large Response Range Reflectometric Urea Biosensor Made from Silica-Gel Nanoparticles, Sensors 14, 13186-13209.

[2] Alqasaimeh, M.S., Heng, L.Y., and Ahmad, M., 2007.A Urea Biosensor from Stacked Sol-Gel Films with Immobilized Nile Blue Chromoionophore and Urease Enzyme, Sensors 7: 2251-2262.

[3] Chang, K.M., Chang, C.T., and Chan, K.M., 2010.Development of an Ion Sensitive Field Effect Transistor Based Urea Biosensor with Solid State Reference Systems, Sensors 10:6115-6127.

[4] Das, G., \& Yoon, H.H., 2015. Amperometric urea biosensors based on sulfonated graphene/ polyaniline nanocomposite, International Journal of Nanomedicine 10, 55 66.

[5] Friedman, M., andJuneja, V.K., 2014.Review of Antimicrobial and Antioxidative Activities of Chitosans in Food, Journal of Food Protection 77(9): 1737-1761.

[6] Gaddes, D.E., Demirel, M.C., Reeves, W.B. and Tadigadapa, S., 2015.Remote calorimetric detection of urea via flow injection analysis, Analyst 140(23), 8033-8040.

[7] Hilding-Ohlsson, A., Fauerbach, J.A., Sacco, N.J., Bonetto, M.C., and Cortón, E., 2012. Voltamperometric Discrimination of Urea and Melamine Adulterated Skimmed Milk Powder, Sensors 12: 12220-12234.

[8] Ho, W.O., Krause, S., McNeil, C.J., Pritchard, J.A., Armstrong, R.D., Athey, D. and Rawson, K., 1999. Electrochemical sensor for measurement of urea and creatinine in serum based on ac impedance measurement of enzyme-catalyzed polymer transformation, Analytical Chemistry 71: 1940-1946.

[9] Liu, L., Mo, H., Wei, S., and Raftery, D., 2012. Quantitative analysis of urea in human urine and serum by 1H nuclear magnetic resonance, Analyst 137(3): 595-600.

[10] Lue, C.E., Yu, T.C., Yang, C.M., Pijanowska, D.G. and Lai, C.S., 2011. Optimization of Urea-EnFET Based on Ta2O5 Layer with Post Annealing, Sensors 11: 4562-4571.

[11] Ma, W.J., Luo, C.H., Lin, J.L., Chou, S.H., Chen, P.H., Syu, M.J., Kuo, S.H., and Lai, S.C., 2016. A Portable Low-Power Acquisition System with a Urease Bioelectrochemical Sensor for Potentiometric Detection of Urea Concentrations, Sensors 16: 474..

[12] Manea, F., Pop, A., Radovan, C., Malchev, P., Bebeselea, A., Burtica, G., Picken, S., and Schoonman, J., 2008. Voltammetric Detection of Urea on an Ag-Modified ZeoliteExpanded Graphite-Epoxy Composite Electrode, Sensors 8:5806-5819.

[13] Pitiranggon, M., Perzanowski, M.S., Kinney, P.L., Xu, D., Chillrud, S.N. and Yan, B., 2014. Determining Urea Levels in Exhaled Breath Condensate with Minimal Preparation Steps and Classic LC-MS, Journal of Chromatographic Science 52: 10261032.

[14] Sharma., Minakshi, S., Kumar, V., Kumar, J., and Pundir, C.S., 2009. Preparation of reusable enzyme strips using alkylamine and arylamine glass beads affixed on plastic 
strips for urea determination, Indian Journal of Chemical Technology (IJCT)16: 357360 .

[15] Sihombing, E., Situmorang, M., Sembiring, T., and Nasruddin, 2015. The Development Of Mercury Ion Selective Electrode With Ionophore 7,16-Di-(2-methylquinolyl)1,4,10,13-tetraoxa-7,16-diazacyclooctadecane (DQDC), Modern Applied Science 9(8): 81-90.

[16] Sihombing, K., Situmorang, M., and Hutabarat, W., 2017. Pengembangan Sensor Elektrokimia Untuk Penentuan Uream, Prosiding Seminar Nasional dan Rapat Tahunan BKS PTN-B Bidang MIPA di Ratu Convention Center (RCC) Kota Jambi, Jambi, 12 14 Mei 2017: pp. 1742-1748.

[17] Sihombing, K., Tamba, M.C., Marbun, W.S., and Situmorang, M., 2018. Urease immobilized potentiometric biosensor for determination of urea, Indian Journal of Chemistry 57A(2): 175-180.

[18] Situmorang, M., and Nurwahyuni, I. 2017. Urease immobilized potentiometric biosensor for determination of urea, Indones. J. Chem 17(3): 461-470.

[19] Situmorang, M., and Nurwahyuni, I. 2018. Biosensor Elektrokimia Untuk Penentuan Asam Urat, Indonesian Patent No. IDP000051693, 09 July 2018.

[20] Situmorang, M., Gooding, J.J., and Hibbert, D.B., 1999. Immobilisation of Enzyme Throughout a Polytyramine Matrix: A Versatile Procedure for Fabricating Biosensors, Analytica Chimica Acta 394(2-3): 211-223.

[21] Situmorang, M., Gooding, J.J., Hibbert, D.B. and Barnett, D., 2001.Development of potentiometric biosensors using electrodeposited polytyramine as the enzyme immobilisation matrix, Electroanalysis 13(18): 1469-1474.

[22] Situmorang, M., Gooding, J.J., Hibbert, D.B., and Barnett, D., 2002. The Development of a Pyruvate Biosensor Using Electrodeposited Polytyramine, Electroanalysis 14(1): 17-21., ISSN 1040-0397.

[23] Situmorang, M., Gooding, J.J.,Hibbert, D.B., and Barnett, D., 1998. Electrodeposited polytyramine as an immobilisation matrix for enzyme biosensors, Biosensors \& Bioelectronics 13(9): 953-962.

[24] Situmorang, M., Hibbert, D.B., and Gooding, J.J., 2000. An Experimental Design Study of Interferences of Clinical Relevance of a Polytyramine Immobilized-Enzyme Biosensor, Electroanalysis 12(2): 111-119.

[25] Situmorang, M., Simanjuntak, E.P., and Silaen, D, 2010. Pengembangan Metode Analisis Spektrofotometry Melalui Reaksi Enzimasi Untuk Penentuan Glukosa di Dalam Buah-Buahan, JurnalSain Indonesia 34(3): 8-14.

[26] Situmorang, M.; Alexander, P.W. and Hibbert, D.B., 1998. Flow injection potentiometry for enzymatic assay of cholesterol with a tungsten electrode sensor, Talanta 49(3): 639-649.

[27] Tan, H., Cha, W., Chen, J., Yao, S., 1998. A response model for surface acoustic wave enzyme sensor applied to the kinetic study of urease-catalytic reaction and urea determination, Indian Journal of Chemistry 37A: 288-294.

[28] Ulianas, A., Heng, L.Y., and Ahmad, M., 2011. A Biosensor for Urea from Succinimide-Modified Acrylic Microspheres Based on Reflectance Transduction, Sensors 11: 8323-8338.

[29] Zawada, R.J.X., Kwan, P., Olszewski, K.L., Llinas, M., and Huang, S.G., 2009. Quantitative determination of urea concentrations in cell culture medium, Biochem Cell Biol. 87(3): 541-544 